\title{
Hydrogeochemical analysis and evaluation of groundwater quality in the Gadilam river basin, Tamil Nadu, India
}

\author{
M V Prasanna ${ }^{1, *}$, S Chidambaram ${ }^{2}$, A Shahul Hameed ${ }^{3}$ and K Srinivasamoorthy ${ }^{2}$ \\ ${ }^{1}$ School of Engineering and Science, Department of Applied Geology, Curtin University, \\ Sarawak Campus, CDT 250, 98009 Miri, Sarawak, Malaysia. \\ ${ }^{2}$ Department of Earth Sciences, Annamalai University, Annamalainagar 608 002, India. \\ ${ }^{3}$ Centre for Water Resources Development and Management, Kozhikode, Kerala, India. \\ *e-mail: geoprasanna@rediffmail.com
}

\begin{abstract}
Water samples were collected from different formations of Gadilam river basin and analyzed to assess the major ion chemistry and suitability of water for domestic and drinking purposes. Chemical parameters of groundwater such as $\mathrm{pH}$, electrical conductivity (EC), total dissolved solids (TDS), Sodium $\left(\mathrm{Na}^{+}\right)$, Potassium $\left(\mathrm{K}^{+}\right)$, Calcium $\left(\mathrm{Ca}^{+}\right)$, Magnesium $\left(\mathrm{Mg}^{+}\right)$, Bicarbonate $\left(\mathrm{HCO}_{3}{ }^{-}\right)$, Sulphate $\left(\mathrm{SO}_{4}{ }^{-}\right)$, Phosphate $\left(\mathrm{PO}_{4}{ }^{-}\right)$and Silica $\left(\mathrm{H}_{4} \mathrm{SiO}_{4}\right)$ were determined. The geochemical study of the aquatic systems of the Gadilam river basin show that the groundwater is near-acidic to alkaline and mostly oxidizing in nature. Higher concentration of Sodium and Chloride indicates leaching of secondary salts and anthropogenic impact by industry and salt water intrusion. Spatial distribution of EC indicates anthropogenic impact in the downstream side of the basin. The concentration levels of trace metals such as Iron (Fe), Lead (Pb), Nickel (Ni), Bromide (Br), Iodide (I) and Aluminium (Al) have been compared with the world standard. Interpretation of data shows that some trace metals such as $\mathrm{Al}, \mathrm{Ni}$ and $\mathrm{Pb}$ exceed the acceptable limit of world standard. Geophysical study was carried out to identify the weathered zone in the hard rock and contaminated zone by anthropogenic impact in the downstream of river Gadilam. A few of the groundwater samples in the study area were found to be unsuitable for domestic and drinking purposes.
\end{abstract}

\section{Introduction}

Geochemical processes occurring within the groundwater and reactions with aquifer minerals have a profound effect on water quality. Hydrogeochemical composition of groundwater can also be indicative of its origin and history of the passage through underground materials with which water has been in contact. Groundwater contains dissolved minerals from the soil layers through which it passes. It may also contain some harmful contaminants through the process of seepage from the surface water and biological activities. On the other hand, the surface water contains a lot of organic matter, mineral nutrients and other contaminants brought by run-off from agriculture fields, fertilizers, pesticides, soil particles, waste chemicals from industries and sewage of cities and rural areas. The water bodies are continuously subjected to a dynamic state of change with respect to lithological characteristics and geo-climatic conditions. This dynamic balance in the aquatic system is upset by human activities, resulting in pollution.

Trace element studies of groundwater have attracted researchers for a variety of reasons; their significance related to public health problems, their need in relation to plant growth and the mechanism of metal transport in aqueous environment. Trace

Keywords. Groundwater; major ions; hydrogeochemistry; trace metals; resistivity. 


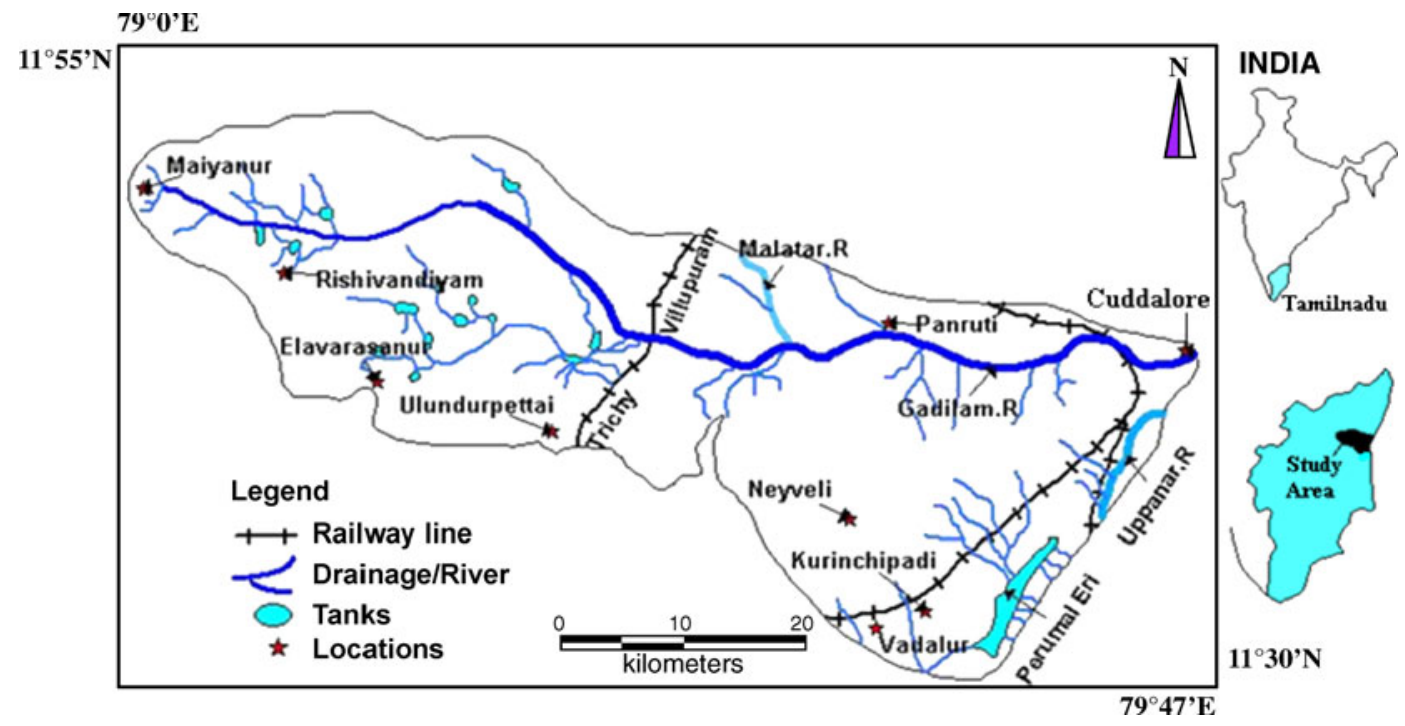

Figure 1. Location map of the study area.

elements in groundwater are defined as chemical elements dissolved in water in minute quantities, always or almost always in concentration of less than $1 \mathrm{mg}$ of trace element in one liter of water (USGS 1993). The study of quantity of water alone is not sufficient to solve the water management problems because its uses for various purposes depend on its quality. Hence, the hydrogeochemical character of groundwater and groundwater quality in different aquifers over space and time have proven to be important in solving the problems (Panigrahy et al 1996; Atwia et al 1997; Ballukraya and Ravi 1999; Ramappa and Suresh 2000). Similar studies were done by Lakshmanan et al (2003); Mondal and Singh (2004); Rabemanana et al (2005); Das Brijraj and Kaur (2007); Singh Abhay et al (2007) and Sadashivaiah et al (2008).

Geophysical resistivity surveys are regularly used for studies related to groundwater investigations. Resistivity profiling delineates the lateral changes in resistivity of the formation that can be correlated with steeply dipping interfaces between two geological formations in the subsurface. Resistivity sounding determines the thickness and resistivity of different horizontal or low dipping subsurface layers, including the aquifer zone (Choudhury and Saha 2004). The electrical resistivity method is widely used in groundwater exploration studies (Todd 1959) because it is the least expensive of all the geophysical methods requiring no specially trained technicians to operate the instrument. Water barren formations can be identified based on the contrast in electrical resistivity (Zohdy et al 1974). Characterization of groundwater flow regime by fracture network was carried out with the help of geophysical methods by Deevashish Kumar (2002). Balaram Das et al
(2007) have highlighted the utility of the electrical resistivity method along with chemical data for successful delineation of contaminated/polluted groundwater zones in part of Birbhum district, West Bengal.

Earlier work carried out in the lower sub-basin of river Gadilam consists of sedimentary terrain and coastal alluvium to understand the geochemical processes using major ions and stable isotope (Prasanna et al 2008). There has been limited attempt to study the quality of groundwater using trace metals and geophysical data. Hence, the main objective of this study was to assess the utility of geochemical data including trace metals and geophysical data for delineating the areas suitable for groundwater development in the entire basin (including hard rock and sedimentary formation), for four different seasons.

\section{Study area}

Gadilam river basin is located in parts of Cuddalore and Villupuram districts of Tamil Nadu, India. It lies between $79^{\circ} 0^{\prime} \mathrm{E}$ to $79^{\circ} 47^{\prime} \mathrm{E}$ longitudes and $11^{\circ} 30^{\prime} \mathrm{N}$ to $11^{\circ} 55^{\prime} \mathrm{N}$ latitudes (figure 1 ). It occurs within the Survey of India toposheets of $58 \mathrm{M} / 1,2$, $5,6,9,13,10$ and 14 , covering a total area of about $1394 \mathrm{~km}^{2}$. The Gadilam river basin is bounded by Ponnaiyar river basin in the north and the Vellar river basin in the south. The total length of the river is about $112 \mathrm{~km}$ with a catchment area of about $900 \mathrm{~km}^{2}$. The important large scale groundwater extraction sites in this basin are Neyveli Lignite Corporation (NLC) and the boreholes of New Veeranam Scheme (NVS). The open cast mining of 


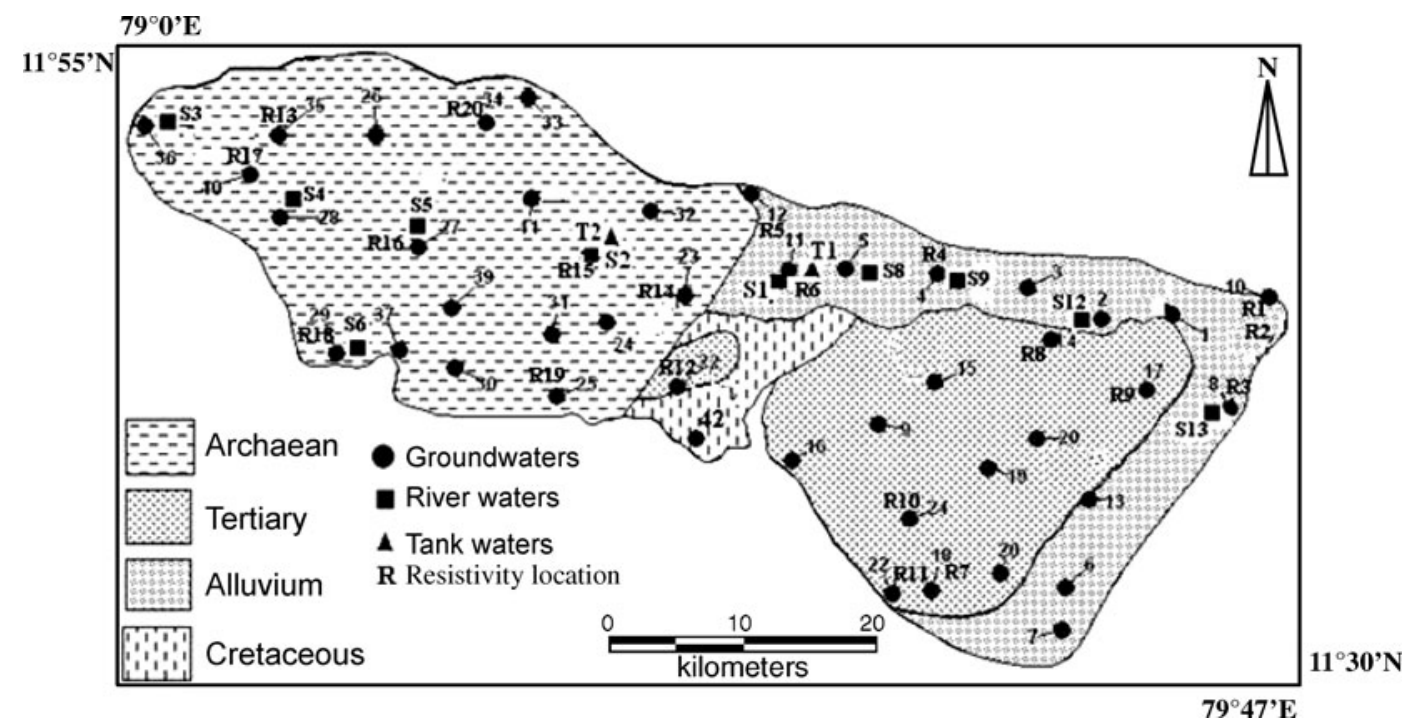

Figure 2. Geology, water sample and resistivity sounding location map.

Lignite requires heavy pumping at the rate of 9000 $10,000 \mathrm{~m}^{3} \mathrm{~h}^{-1}$ as water table condition has to be brought down below the level of mining (Anandhan 2005). Water from the Veeranam Lake is supplied through transmission line to Chennai city. To augment the supply during summer season, 48 deep bore wells were drilled and operations are done alternatively to pump the groundwater from deep aquifer and the pumped water is supplied through the New Veeranam Scheme (NVS) pipelines. Apart from these large scale extraction features, an industrial estate SIPCOT (Small Industries Promotion Corporation of Tamil Nadu) with groups of industries, which generate multi-facet chemicals and raw materials are distributed along the downstream of the river Gadilam, near the coast at Cuddalore (Prasanna 2008). The average annual rainfall of the Cuddalore district is $1902 \mathrm{~mm}$ and that of Villupuram district is around $1384 \mathrm{~mm}$ (India Meteorological Department, 2004-2006). The water level varies from 3.10 to 48.85 bgl (below ground level) with an average of $12.37 \mathrm{bgl}$ (Tamil Nadu Water and Drainage Board, 2005-2006). Gadilam river originates in the hard rock region and passes through the sedimentary terrain. Rock types of different stratigraphic units are exposed in the basin (figure 2). The charnockites, leptinites, schists and gneiss of Archaean complex constitute the upstream area. The younger Cretaceous and Tertiary formations are found in midstream and the recent Alluvium is found in the downstream of the Gadilam basin. Lithologically, hard rocks characterize the western part of the basin with the dominance of pediments. The northern part is essentially covered by flood plain and recent Alluvium.

\section{Methodology}

\subsection{Major ions}

The water samples were collected (figure 2) during March 2005, July 2005, January 2006 and November 2006 to broadly cover seasonal variation. A total of 178 water samples were collected from bore wells (156), river (14) and tank (8) in four different seasons (November 2006 represents NE monsoon; January 2006 represents postmonsoon; March 2005 represents Summer; July 2005 represents SW monsoon). In summer (SUM) and southwest monsoon (SWM), 12 groundwater samples were collected from Alluvium, 10 groundwater samples from Tertiary, 14 groundwater samples from Archaean and two surface water samples from tank. In northeast monsoon (NEM) and post-monsoon (POM), 12 groundwater samples were collected from Alluvium, 12 groundwater samples from Tertiary, 17 groundwater samples from Archaean, one groundwater sample from Cretaceous, seven surface water samples from river and two surface water samples from tank. Cretaceous formation covers less than $5 \%$ of the study area. In certain locations during summer and southwest monsoon periods the wells were dry. River Gadilam is an ephemeral river, as the water flows only during NEM and POM periods.

Water samples of one litre were collected in polyethylene bottles, four times a year. The bottles were sealed, sent to the laboratory and stored properly at $4^{\circ} \mathrm{C}$ before analysis.

The samples collected were analyzed for major cations like, $\mathrm{Ca}$ and $\mathrm{Mg}$ by Titrimetry, $\mathrm{Na}$ and $\mathrm{K}$ by Flame photometer (CL 378); anions, $\mathrm{Cl}$ and 
$\mathrm{HCO}_{3}$ by Titrimetry, $\mathrm{SO}_{4}, \mathrm{PO}_{4}$ and $\mathrm{H}_{4} \mathrm{SiO}_{4}$ by Spectrophotometer (SL 171 minispec). The EC and $\mathrm{pH}$ were determined in the field using electrode (Eutech). The TDS was also measured in situ by TDS portable electrode model TDS Testr11+ (multi-range). The analyses were done by adopting standard procedures (APHA 1998). The analytical precision for the measurements of cations and anions was determined by calculating the ionic balance error that varies by about $5-10 \%$ (Domenico and Schwartz 1998; Srinivasamoorthy et al 2008).

\subsection{Trace metals}

Twenty-nine groundwater and seven surface water (river water) samples were analysed during the post-monsoon period (figure 2). Before the estimation of dissolved metals, the samples were filtered through $0.45 \mu \mathrm{m}$ membrane filter paper using vacuum pump. The samples were then spiked with the standard solution of the metals chosen for analysis. This standard addition method was adopted to achieve greater accuracy in the analysis of trace metals such as $\mathrm{Fe}, \mathrm{Pb}, \mathrm{Ni}, \mathrm{Br}, \mathrm{I}$ and $\mathrm{Al}$. Fe was analyzed in Atomic Adsorption Spectrophotometer (AAS), (Model - SL 176, Elico Limited, Hyderabad, India) with a spectral range of $185-930 \mathrm{~nm}$ and $\pm 0.5 \mathrm{~nm}$ accuracy. $\mathrm{Pb}, \mathrm{Ni}$ and $\mathrm{Al}$ were analysed in AAS (Model - Shimadzu-AA-6800), Br and I were analysed in ion electrodes (Model - CONSORT).

\subsection{Geophysical survey}

Resistivity sounding was carried out to cover major litho units in the study area (figure 2). The resistivity survey was done with the help of SSR-MP-AT resistivity meter (IGIS, Hyderabad, India), adopting Schlumberger electrode configuration method. The apparent resistivity of the sub-surface formation was determined and the results were manually plotted by curve matching method.

\section{Results and discussion}

\subsection{Geochemical investigation}

\subsubsection{Water chemistry}

The average, mean, and standard deviation values for chemical composition of the groundwater samples collected during four different seasons, viz., northeast monsoon (NEM), post-monsoon (POM), summer (SUM) and southwest monsoon (SWM) in different formations are given in tables 1 and 2 . The total cations $\left(\mathrm{TZ}^{+}\right)$and total anions $\left(\mathrm{TZ}^{-}\right)$balance (Freeze and Cherry 1979) was considered to show the charge balance error percentage. The error percentage in the samples of the present study ranged between $\pm 1 \%$ and $\pm 10 \%$. Occurrence of errors in chemical analysis of groundwater is also due to the reagents employed, limitations of the methods, the instruments used and the presence of impurities in distilled water, etc. The correlation coefficient between $\mathrm{TZ}^{+}$and $\mathrm{TZ}^{-}$is around 0.6 to 0.9 . The TDS/EC ratio was in the range of $0.5-0.9$. The role played by other ions than those considered in the study for the cations and anions charge balance is less significant. The groundwater in the study area was generally odourless and colourless in most of the places.

In Alluvium formation, $\mathrm{Cl}$ was the dominant anion followed by $\mathrm{HCO}_{3}, \mathrm{SO}_{4}$ and $\mathrm{PO}_{4}$ during SUM, NEM and POM seasons. But in SWM, $\mathrm{HCO}_{3}$ was the dominant anion followed by $\mathrm{Cl}, \mathrm{SO}_{4}$ and $\mathrm{PO}_{4}$. In $\mathrm{POM}, \mathrm{Na}$ was the dominant cation followed by Ca, K and Mg. But in SUM, SWM and $\mathrm{NEM}, \mathrm{Na}$ was the dominant cation followed by $\mathrm{Ca}$, $\mathrm{Mg}$ and $\mathrm{K}$.

In Tertiary formation, $\mathrm{Cl}$ was the dominant anion followed by $\mathrm{SO}_{4}, \mathrm{HCO}_{3}$ and $\mathrm{PO}_{4}$ during SUM. In POM, Cl was the dominant anion followed by $\mathrm{HCO}_{3}, \mathrm{SO}_{4}$ and $\mathrm{PO}_{4}$. In $\mathrm{SWM}, \mathrm{HCO}_{3}$ was the dominant anion followed by $\mathrm{SO}_{4}, \mathrm{Cl}$ and $\mathrm{PO}_{4}$. In $\mathrm{NEM}, \mathrm{HCO}_{3}$ was the dominant anion followed by $\mathrm{Cl}, \mathrm{SO}_{4}$ and $\mathrm{PO}_{4}$. In SUM, NEM and POM, Na was the dominant cation followed by $\mathrm{Ca}, \mathrm{K}$ and $\mathrm{Mg}$. But in SWM, Na was the dominant cation followed by $\mathrm{Ca}, \mathrm{Mg}$ and $\mathrm{K}$.

In Archaean formation, $\mathrm{HCO}_{3}$ was the dominant anion followed by $\mathrm{Cl}, \mathrm{SO}_{4}$ and $\mathrm{PO}_{4}$ during SUM, SWM and NEM seasons. But in POM, Cl was the dominant anion followed by $\mathrm{HCO}_{3}, \mathrm{SO}_{4}$ and $\mathrm{PO}_{4}$. In SUM, SWM and POM, Na was the dominant cation followed by $\mathrm{Ca}, \mathrm{K}$ and $\mathrm{Mg}$. But in NEM, $\mathrm{Na}$ was the dominant cation followed by $\mathrm{Ca}, \mathrm{Mg}$ and $\mathrm{K}$.

In tank water, $\mathrm{Cl}$ was the dominant anion followed by $\mathrm{HCO}_{3}, \mathrm{SO}_{4}$ and $\mathrm{PO}_{4}$ irrespective of the seasons. Na was the dominant cation followed by $\mathrm{Ca}, \mathrm{K}$ and $\mathrm{Mg}$ irrespective of the seasons. In river water, $\mathrm{HCO}_{3}$ was the dominant anion followed by $\mathrm{Cl}, \mathrm{SO}_{4}$ and $\mathrm{PO}_{4}$ irrespective of the seasons. In NEM, Na was the dominant cation followed by Ca, $\mathrm{Mg}$ and $\mathrm{K}$. But in POM, Na was the dominant cation followed by $\mathrm{Ca}, \mathrm{K}$ and $\mathrm{Mg}$.

The Durov diagram was used to infer hydrogeochemical facies. Chemical data of representative samples from the study area are presented by plotting them on Durov plot for all the seasons. In NEM and POM, the samples of Alluvium formation (figure 3) were concentrated in $\mathrm{Na}-\mathrm{Cl}$ type indicating saline nature in the groundwater. In SUM and SWM, cluster of samples fell in $\mathrm{Na}-\mathrm{Cl}$ 
Hydrogeochemical study of the groundwater in Gadilam river basin

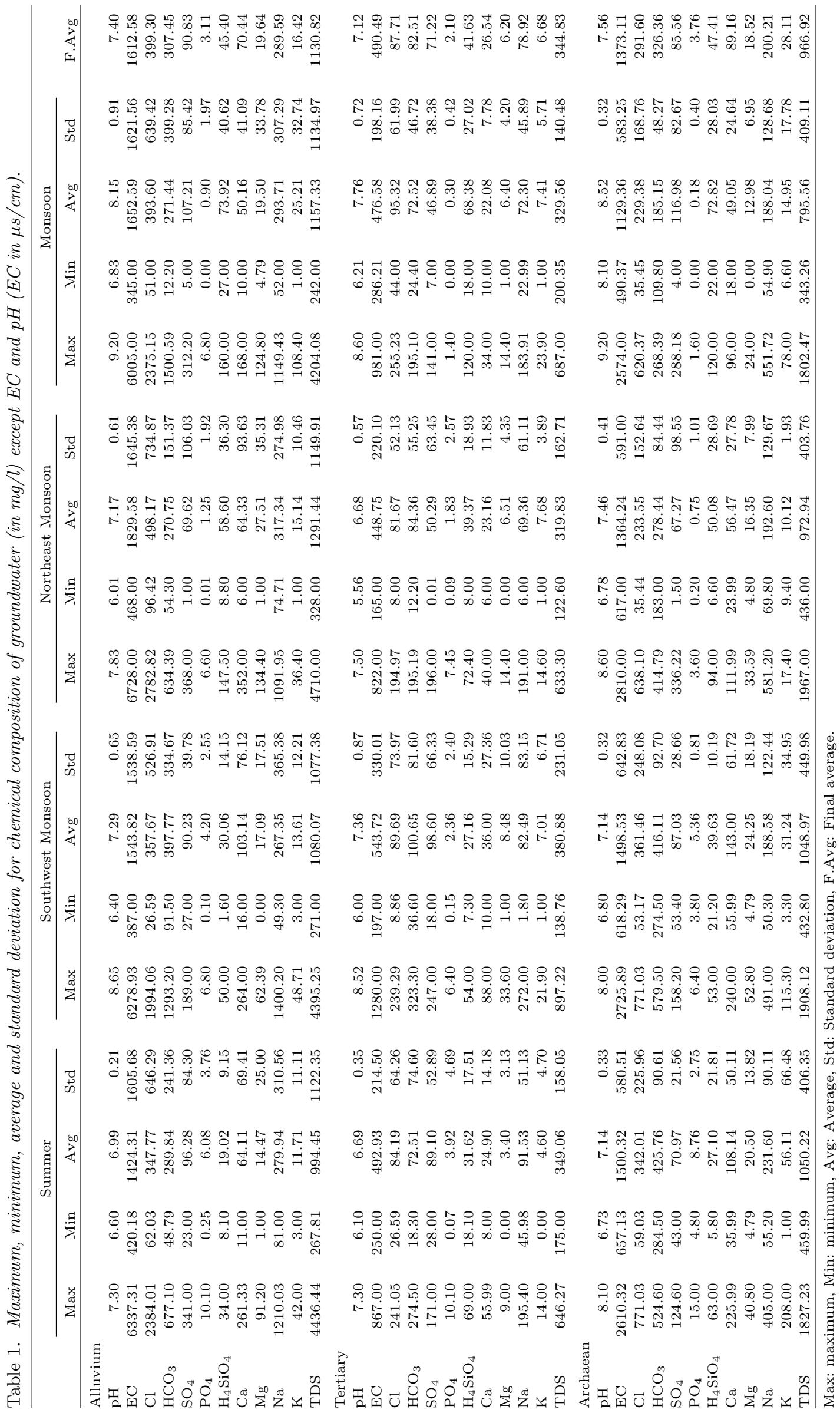




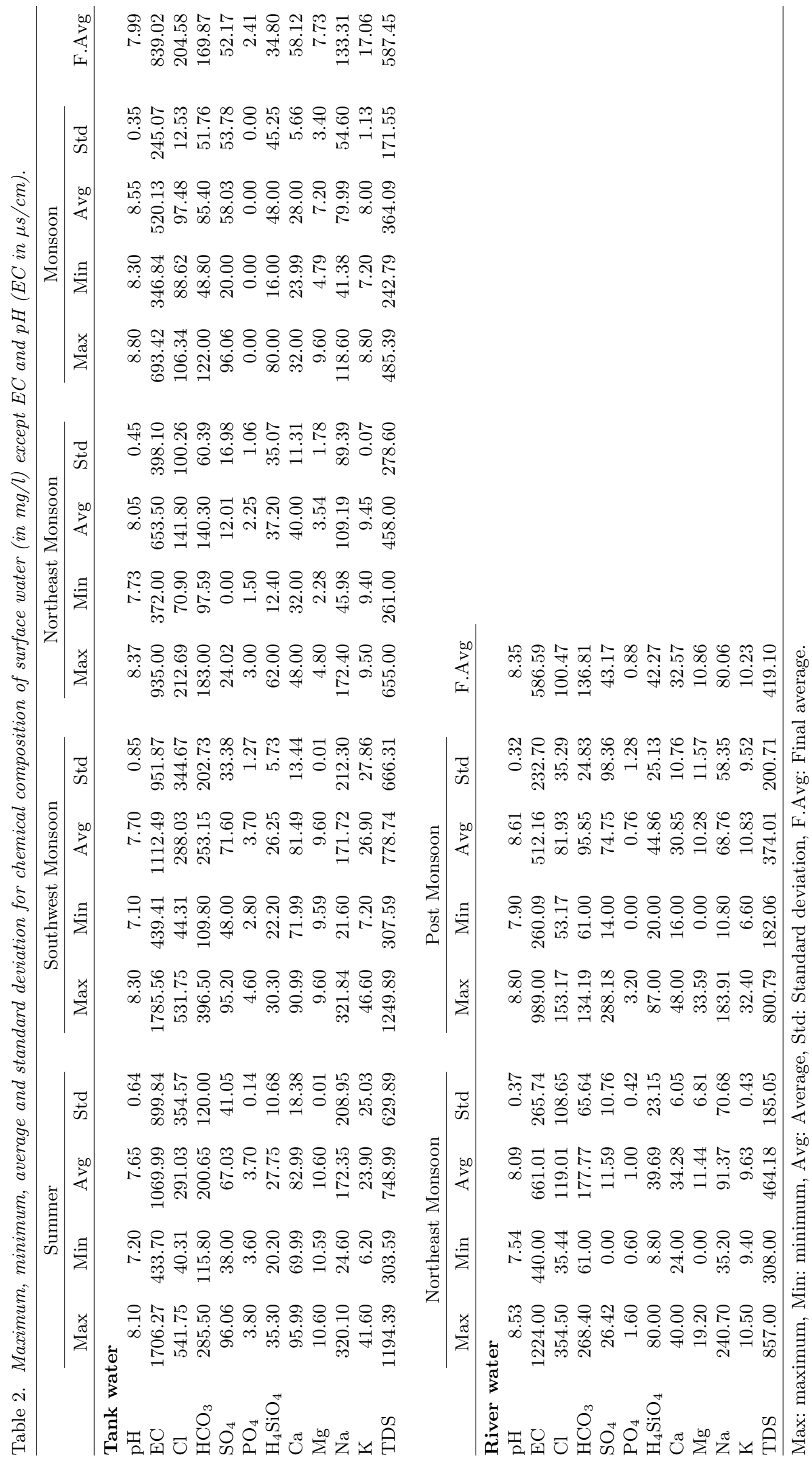


and mixed $\mathrm{Ca}-\mathrm{Na}-\mathrm{HCO}_{3}, \mathrm{Ca}-\mathrm{Mg}-\mathrm{Cl}$ facies. In Tertiary formation (figure 3), SUM and SWM seasons were well represented in the field of $\mathrm{NaCl}$ and mixed $\mathrm{Ca}-\mathrm{Na}-\mathrm{HCO}_{3}$, indicating the dominance of alkaline and strong acids. In NEM and POM, cluster of samples fell in $\mathrm{Na}-\mathrm{Cl}$ type and some samples also represented mixed $\mathrm{Ca}-\mathrm{Mg}-\mathrm{Cl}$ and $\mathrm{Ca}-\mathrm{Cl}$ facies.

In Archaean (figure 3), most of the plots fell in the field of $\mathrm{NaCl}$ with less representation in mixed $\mathrm{Ca}-\mathrm{Na}-\mathrm{HCO}_{3}$ and mixed $\mathrm{Ca}-\mathrm{Mg}-\mathrm{Cl}$. In NEM and POM, alkaline and strong acid were predominant, indicating the intensive weathering action of silicate bearing minerals and secondary leaching of ions (Srinivasamoorthy 2004). In SUM and SWM, majority of samples fell in $\mathrm{Na}-\mathrm{Cl}$ and mixed $\mathrm{Ca}-$ $\mathrm{Mg}-\mathrm{Cl}$ with minor representation from mixed $\mathrm{Ca}-$ $\mathrm{Na}-\mathrm{HCO}_{3}$ and $\mathrm{Ca}-\mathrm{HCO}_{3}$ facies.

In Cretaceous formation (figure 3), NEM samples fell in $\mathrm{Ca}-\mathrm{HCO}_{3}$ facies indicating the dominance of alkali earth and weak acids. But in POM, the plot fell in $\mathrm{Na}-\mathrm{Cl}$ facies indicating the predominance of alkaline and strong acid. In tank waters (figure 3), SUM and SWM samples fell in $\mathrm{Na}-\mathrm{Cl}$ and mixed $\mathrm{Ca}-\mathrm{Mg}-\mathrm{Cl}$ facies. In NEM and POM, most of the samples fell in $\mathrm{Na}-\mathrm{Cl}$ facies indicating the dilution of secondary salt precipitation. In river water (figure 3), cluster of samples during POM is noted in $\mathrm{Na}-\mathrm{Cl}$ facies and NEM samples fell in mixed $\mathrm{Ca}-\mathrm{Na}-\mathrm{HCO}_{3}, \mathrm{Ca}-\mathrm{HCO}_{3}$ and mixed $\mathrm{Ca}-\mathrm{Mg}-\mathrm{Cl}$ facies. In general, the plot shows that alkali $(\mathrm{Na})$ exceeds alkaline earth $(\mathrm{Ca}$ and $\mathrm{Mg}$ ) and strong acid $\mathrm{Cl}$ and $\mathrm{SO}_{4}$ exceeds the weak acids $\left(\mathrm{HCO}_{3}\right)$ in all the litho units irrespective of season.

The attribute values of the specific locations were used to create a spatial data in order to obtain an overall behaviour of the electrical conductivity in the study area. The spatial data of electrical conductivity gives a general trend of the characteristics of the anions and cations present in water. This initially provides first-hand information about the geochemically active regimes (Srinivasa Rao et al 1997; Chidambaram 2000; Srinivasamoorthy 2004; Anandhan 2005). Spatial distribution of EC of samples was done for all four major seasons (figure 4). The study revealed that in SUM and SWM seasons, EC was higher in the regions covered by the Archaean formation in the upstream side and along the downstream side near the coastal areas. In NEM and POM seasons, higher concentration was observed in the upstream side along the lithological boundaries and near the coastal area. This indicates the leaching of secondary salts in the upstream side and anthropogenic activities in the downstream side.

Table 3 shows the range of ionic concentration in groundwater of the study area and prescribed specifications of WHO (2004) and ISI (1995). The groundwater was generally colourless and odourless in all major litho units. Groundwater was near-acidic to alkaline (5.56 to 9.20) and mostly oxidizing. Parameters exceeding permissible limits were identified in most of the locations indicating higher ionic concentration. $\mathrm{Na}, \mathrm{Cl}$ and $\mathrm{K}$ exceeded the permissible limit in all the litho units. $\mathrm{Ca}, \mathrm{Mg}, \mathrm{HCO}_{3}$ and $\mathrm{SO}_{4}$ also exceeded the permissible limit of WHO (2004) standard except in Tertiary formation. But $\mathrm{HCO}_{3}$ was within the permissible limit of ISI (1995) standard except in Alluvium formation indicating the precipitation of $\mathrm{CO}_{3}$ as scales in pipelines (Rengarajan and Balasubramanian 1990). Few of the groundwater samples in the study area were found to be unsuitable for domestic and drinking purposes.

\subsubsection{Trace metals pollution}

To understand the variation of trace metals such as $\mathrm{Fe}, \mathrm{Pb}, \mathrm{Ni}, \mathrm{Br}, \mathrm{I}$ and $\mathrm{Al}$ in the study area after the monsoon period, samples were collected and analysed (figure 5). Iron is an essential element in the metabolism of animals and plants. If it is present in water in excessive amounts, it forms red oxyhydroxide precipitates that stain laundry and plumbing fixtures and, therefore, is an objectionable impurity in domestic and industrial water supplies. For this reason, iron determinations are commonly included in chemical analyses of water. The recommended upper limit for iron in public water supplies is $0.3 \mathrm{mg} / \mathrm{l}$ (NAS-NAE 1972).

The Fe plays a biogeochemical role in the life cycle of plants and animals. Its presence in groundwater with high concentration is unsuitable (Ballukaraya and Ravi 1999). In Alluvium formation, Fe varied from 0.09 to $0.41 \mathrm{mg} / \mathrm{l}$ with an average of $0.17 \mathrm{mg} / \mathrm{l}$. Higher concentration of $\mathrm{Fe}$ in groundwater was derived from nearby laterites capping in Cuddalore and Panruti regions of the basin (Prasanna 2008). In Tertiary formation, Fe varied from 0.02 to $0.29 \mathrm{mg} / \mathrm{l}$ with an average of $0.10 \mathrm{mg} / \mathrm{l}$. Higher concentration of Fe in groundwater may be attributed to the weathering of marcasite and iron oxide coating in sediments which might have contributed this ion (Anandhan 2005). In Archaean formation, Fe varied from 0.03 to $0.19 \mathrm{mg} / \mathrm{l}$ with an average of $0.11 \mathrm{mg} / \mathrm{l}$. The Fe in all of the surface water bodies (river water) exceeds the average levels in the world's rivers (Taylor and McLennan 1985) ranging from 0.11 to $0.41 \mathrm{mg} / \mathrm{l}$ with an average of $0.21 \mathrm{mg} / \mathrm{l}$. Generally higher concentration was observed in Alluvium followed by Tertiary and Archaean formations.

Aluminium is the most abundant metallic element and constitutes about $8 \%$ of the Earth's 

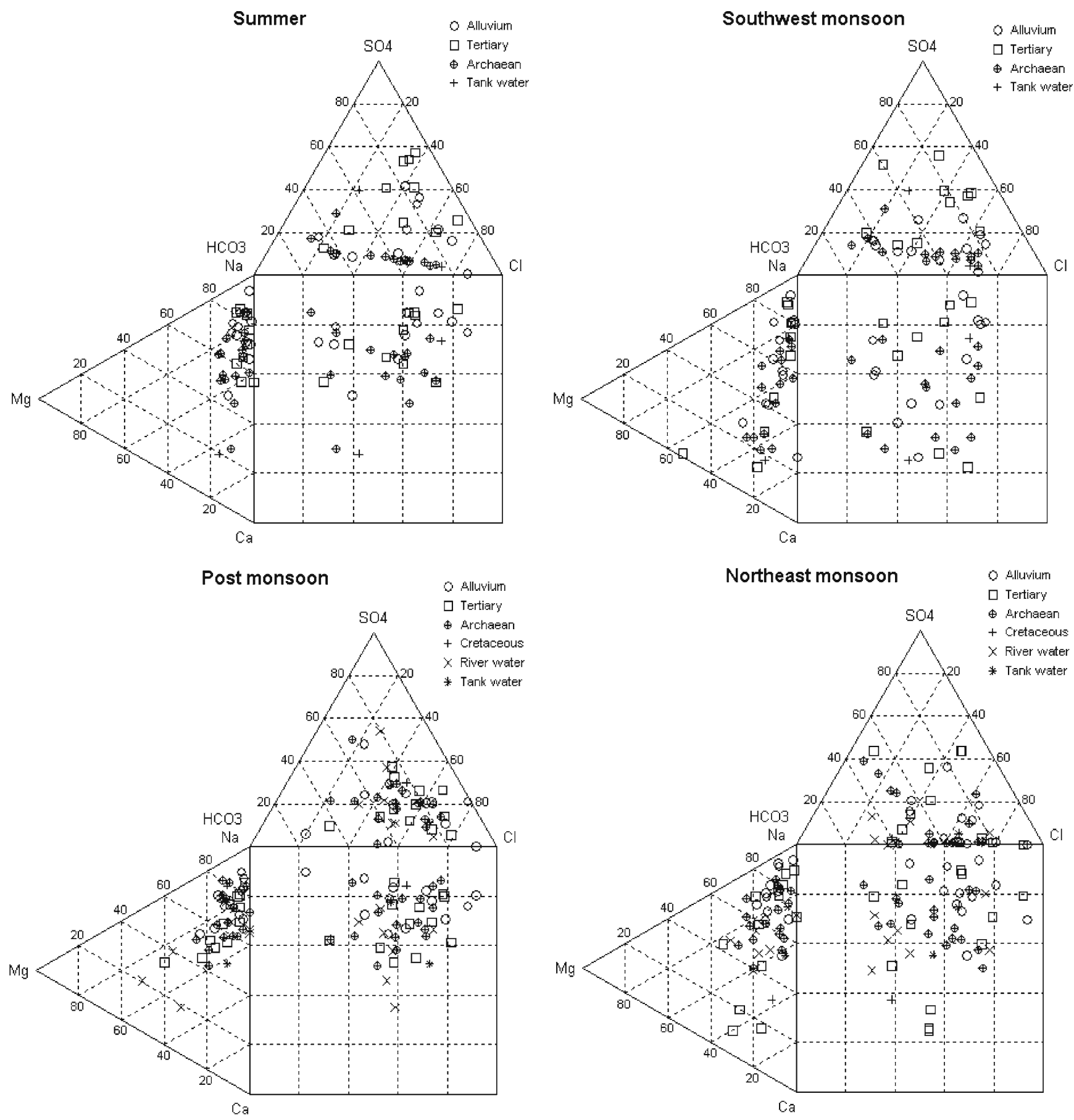

Figure 3. Durov diagram for water classification.

crust. Aluminium salts are widely used in water treatment as coagulants to reduce organic matter, colour, turbidity and micro-organism levels. Aluminium occurs in substantial amounts in many silicate igneous rock minerals such as the feldspars, the feldspathoids, the micas and many amphiboles.

In Alluvium formation, $\mathrm{Al}$ varied from 0.011 to $2.800 \mathrm{mg} / \mathrm{l}$ with an average of $1.054 \mathrm{mg} / \mathrm{l}$, whereas in Tertiary formation, it varied from 0.004 to $2.300 \mathrm{mg} / \mathrm{l}$ with an average of $0.917 \mathrm{mg} / \mathrm{l}$.
In Archaean formation, $\mathrm{Al}$ varied from 0.032 to $2.740 \mathrm{mg} / 1$ with an average $0.741 \mathrm{mg} / \mathrm{l}$. In surface water, it varied from 0.097 to $2.380 \mathrm{mg} / \mathrm{l}$ with an average of $0.723 \mathrm{mg} / \mathrm{l}$. Generally higher concentration was observed in Archaean followed by Alluvium and Tertiary formations.

The concentration of nickel in drinking-water is normally less than $0.02 \mathrm{mg} / \mathrm{l}$, although nickel released from taps and fittings may contribute up to $1 \mathrm{mg} / \mathrm{l}$. In special cases of release from natural 

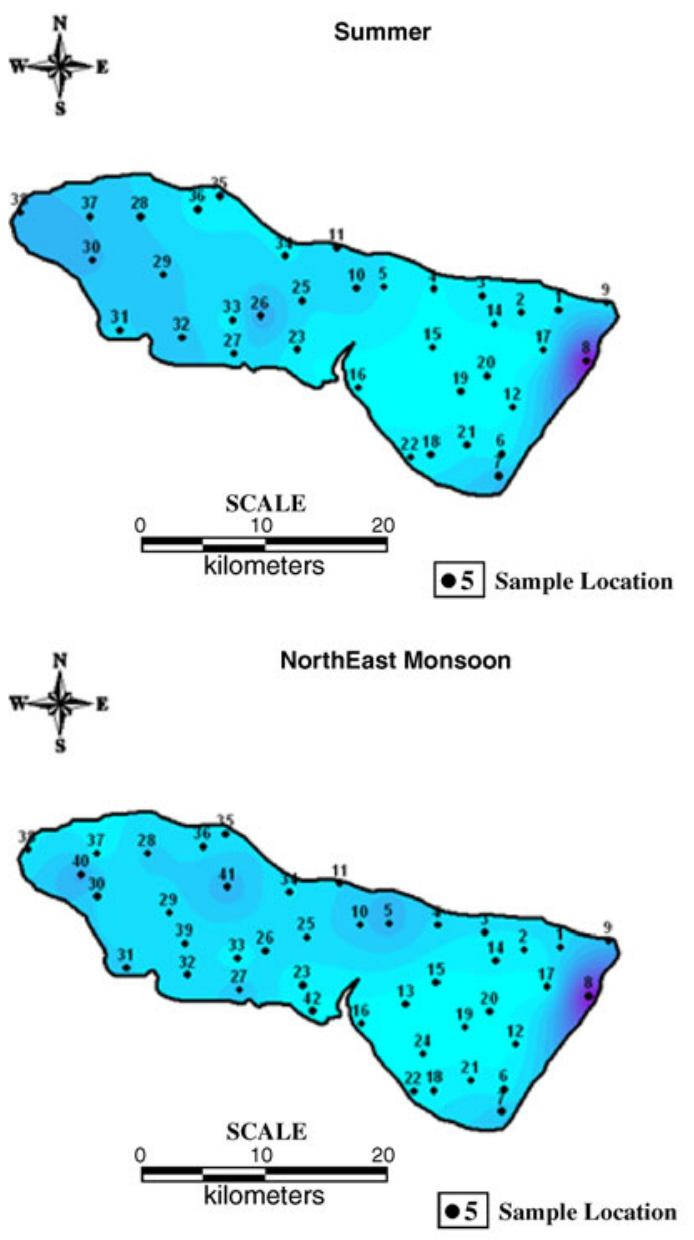
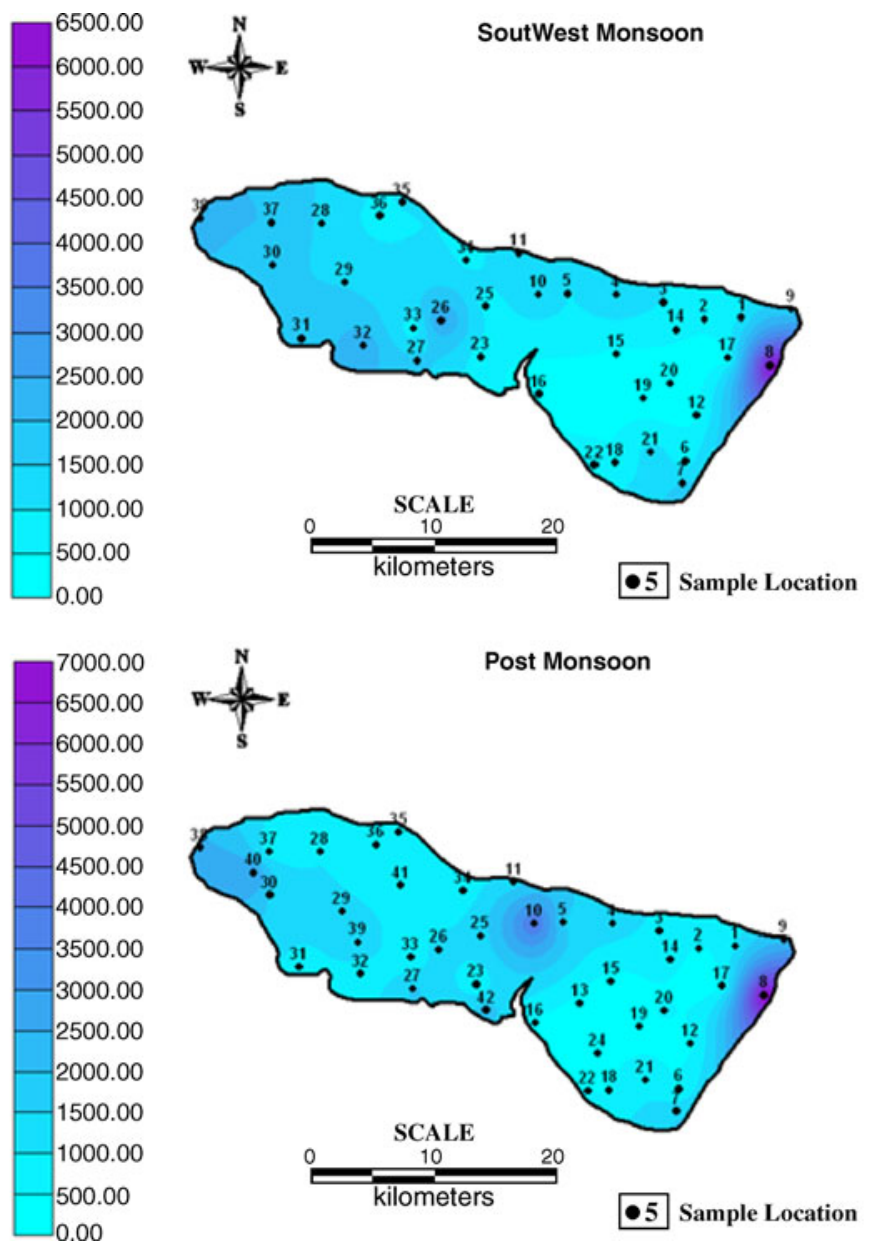

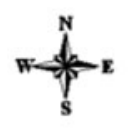

SoutWest Monsoon
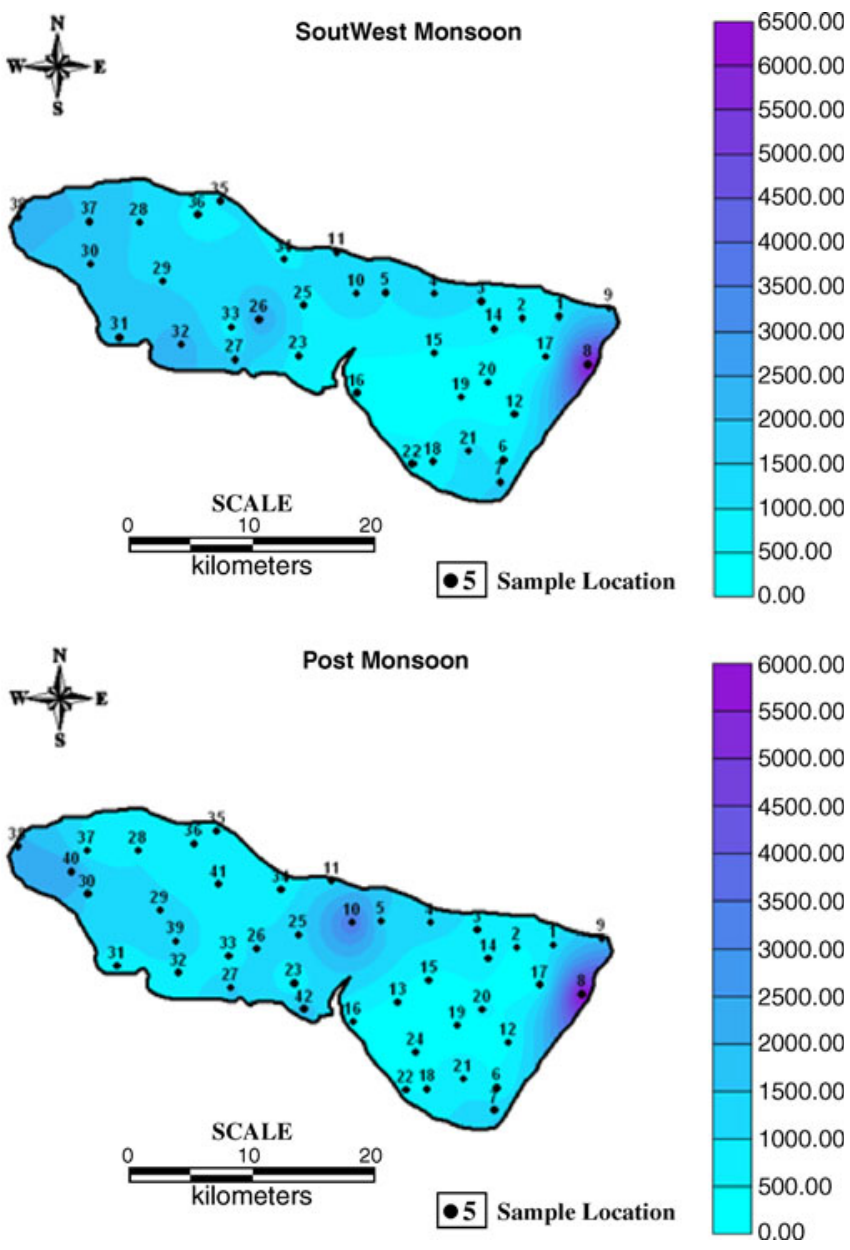

6000.00 500.00 5000.00 500.00 000.00 500.00 3000.00 500.00 000.00 500.00 0.00 0.00

Figure 4. Spatial distribution of EC (in $\mu \mathrm{s} / \mathrm{cm})$.

or industrial nickel deposits to the ground, the nickel concentrations in drinking-water may be higher (WHO 2004). In Alluvium formation, Ni varied from 0.001 to $0.742 \mathrm{mg} / \mathrm{l}$ with an average of $0.130 \mathrm{mg} / \mathrm{l}$. In Tertiary formation, $\mathrm{Ni}$ varied from 0.015 to $0.134 \mathrm{mg} / \mathrm{l}$ with an average of $0.089 \mathrm{mg} / \mathrm{l}$, whereas in Archaean formation, it varied from 0.005 to $0.163 \mathrm{mg} / \mathrm{l}$ with an average of $0.072 \mathrm{mg} / \mathrm{l}$. The $\mathrm{Ni}$ in all of the surface water bodies (river water) exceeds the average levels in the world's rivers (Taylor and McLennan 1985). It varied from 0.005 to $0.134 \mathrm{mg} / \mathrm{l}$ with an average of $0.066 \mathrm{mg} / \mathrm{l}$. Generally higher concentration was observed in Alluvium followed by Archaean and Tertiary formations.

A study by Schock (1980) of the factors that might affect the corrosiveness of water towards lead pipe indicated that maintaining a tap-water lead concentration below $50 \mu \mathrm{g} / \mathrm{L}$ might be possible by careful control of $\mathrm{pH}$ and alkalinity in water supplies. The guideline value for $\mathrm{Pb}$ is $0.01 \mathrm{mg} / \mathrm{l}$ (WHO 2003). In Alluvium formation, $\mathrm{Pb}$ varied from 0.370 to $8.519 \mathrm{mg} / \mathrm{l}$ with an average of $3.128 \mathrm{mg} / \mathrm{l}$, whereas in Tertiary formation, it varied from 0.001 to $5.556 \mathrm{mg} / \mathrm{l}$ with an average of $2.531 \mathrm{mg} / \mathrm{l}$. In Archaean formation, $\mathrm{Pb}$ varied from 0.370 to $6.667 \mathrm{mg} / \mathrm{l}$ with an average of $3.229 \mathrm{mg} / \mathrm{l}$. In surface water, it varied from 0.001 to $4.444 \mathrm{mg} / \mathrm{l}$ with an average of $2.328 \mathrm{mg} / \mathrm{l}$. Generally higher concentration was observed in Alluvium followed by Archaean and Tertiary formations.

Bromine is similar in chemical behaviour to chlorine but in much less concentration. Bromine in natural water is always present as the bromide ion $\mathrm{Br}$. The concentration present in sea water is $65 \mathrm{mg} / \mathrm{l}$, an amount sufficient to make bromide an important constituent. Bromide concentrations in rainwater and snow range from about 5 to $>150 \mu \mathrm{g} / \mathrm{L}$, and a wider range is given for river water by Fuge (1973). Bromine is extracted commercially from sea water and brines. The presence of small amounts of the element in fresh water is not known to have any ecologic significance. Bromide is generally the most conservative constituent in waters, i.e., it is less affected by chemical reactions such as mineral precipitation or adsorption. 
Table 3. Comparison of chemical composition of water with WHO (2004) and ISI (1995) in mg/l (except $E C$ in $\mu s / c m$ and $p H)$.

\begin{tabular}{llllll}
\hline Parameters & \multicolumn{1}{c}{ Alluvium } & \multicolumn{1}{c}{ Tertiary } & \multicolumn{1}{c}{ Archaean } & WHO (2004) & ISI (1995) \\
\hline EC & $345-6728$ & $165-1280$ & $490.37-2810$ & $1400^{*}$ & - \\
pH & $6.01-9.20$ & $5.56-8.60$ & $6.73-9.20$ & $6.5-8.5$ & $6.5-9.2$ \\
TDS & $242-4710$ & $122.60-897.22$ & $343.26-1967$ & $500-1000$ & 1500 \\
$\mathrm{Ca}$ & $6-352$ & $6-88.00$ & $18-240$ & 100 & 200 \\
$\mathrm{Mg}$ & $1-134$ & $1-33.60$ & $4.79-52.80$ & 50 & 100 \\
$\mathrm{Na}$ & $49.30-1400.20$ & $1.80-272$ & $50.30-581.20$ & 200 & - \\
$\mathrm{K}$ & $1-108.40$ & $1-23.90$ & $1-208$ & 20 & - \\
$\mathrm{HCO}_{3}$ & $12.20-1500.59$ & $12.20-323.30$ & $109.80-579.50$ & $125-350$ & 600 \\
$\mathrm{SO}_{4}$ & $1-368$ & $0.01-247$ & $1.50-336.22$ & 250 & 400 \\
$\mathrm{Cl}$ & $26.59-2782.82$ & $8-255.23$ & $35.44-771.03$ & 250 & 1000 \\
\hline
\end{tabular}

*WHO (1996).
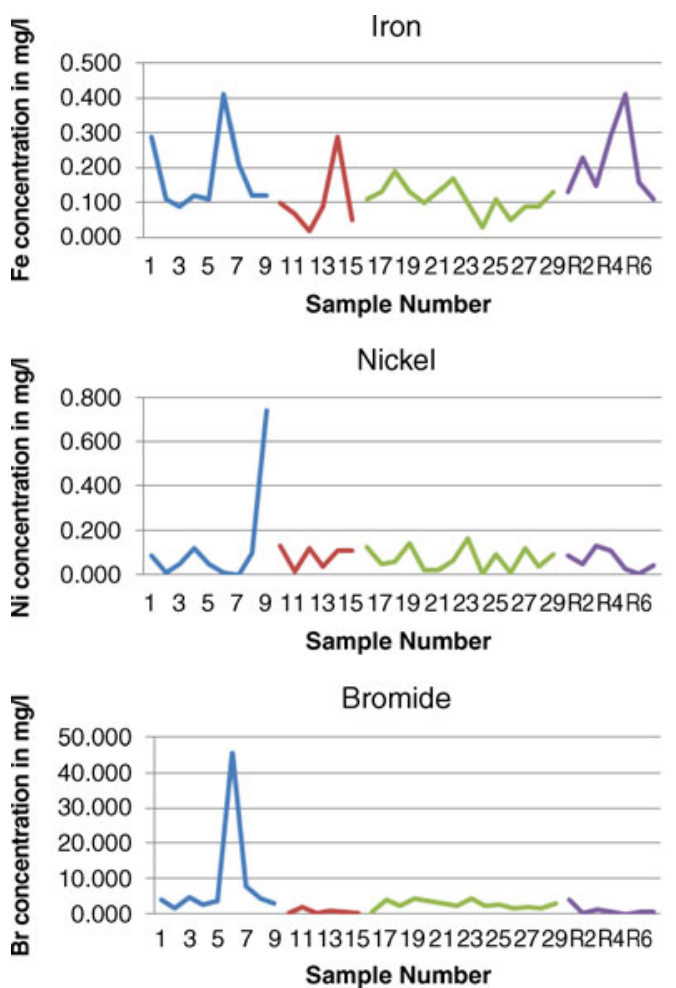
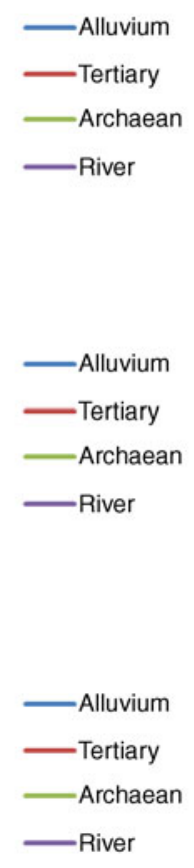
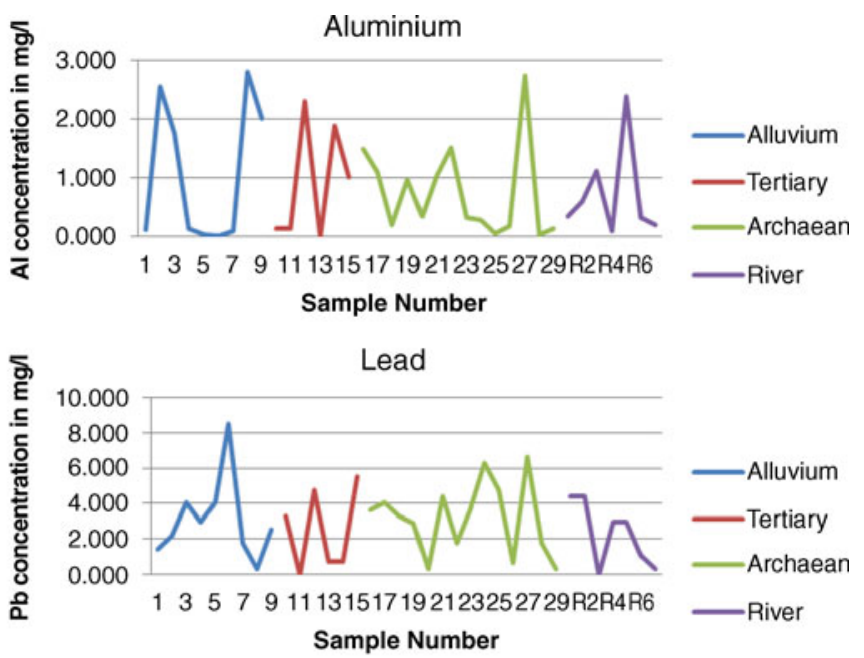

lodide

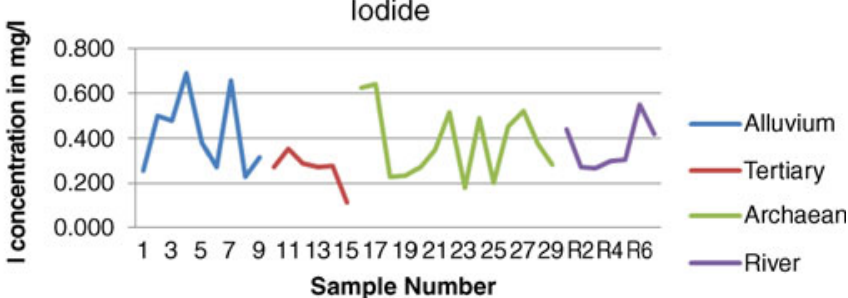

Figure 5. Trace metals concentrations in the study area.

In Alluvium formation, Br varied from 1.630 to $45.600 \mathrm{mg} / \mathrm{l}$ with an average of $8.606 \mathrm{mg} / \mathrm{l}$. Samples showed higher concentration of $\mathrm{Br}$ along the coastal region. This may be attributed to the possibility of sea water intrusion or pollution from local industry. In Tertiary formation, it varied from 0.204 to $2.020 \mathrm{mg} / \mathrm{l}$ with an average of $0.761 \mathrm{mg} / \mathrm{l}$. In Archaean formation, it varied from 0.693 to $4.580 \mathrm{mg} / \mathrm{l}$ with an average of $2.856 \mathrm{mg} / \mathrm{l}$. In surface water, it varied from 0.118 to $4.000 \mathrm{mg} / \mathrm{l}$ with an average of $1.184 \mathrm{mg} / \mathrm{l}$. Generally higher concentration was observed in Alluvium followed by Archaean and Tertiary formations.

Although Iodine (I) is not a particularly abundant element, it is widely distributed. It is essen- tial in the nutrition of animals, humans and its concentrations in natural water have received considerable attention. In Alluvium formation, I value varied from 0.23 to $0.69 \mathrm{mg} / \mathrm{l}$ with an average of $0.42 \mathrm{mg} / \mathrm{l}$. In Tertiary formation, iodide value varied from 0.11 to $0.35 \mathrm{mg} / \mathrm{l}$ with an average of $0.26 \mathrm{mg} / \mathrm{l}$, whereas in Archaean formation, it varied from 0.18 to $0.64 \mathrm{mg} / \mathrm{l}$ with an average of $0.38 \mathrm{mg} / \mathrm{l}$. In surface water, I varied from 0.26 to $0.55 \mathrm{mg} / \mathrm{l}$ with an average of $0.36 \mathrm{mg} / \mathrm{l}$. Generally, higher concentration was observed in Alluvium followed by Archaean and Tertiary formations.

The concentration levels of trace metals were compared against the WHO (1993) standard (table 4). Interpretation of trace metals data shows 
Table 4. Comparison of trace element with WHO (1993) standard.

\begin{tabular}{|c|c|c|c|c|c|c|}
\hline \multirow[b]{2}{*}{ Parameters } & \multicolumn{2}{|c|}{ WHO (1993) standard } & \multirow[b]{2}{*}{$\begin{array}{c}\text { Alluvium } \\
(\mathrm{mg} / \mathrm{l})\end{array}$} & \multirow[b]{2}{*}{$\begin{array}{l}\text { Tertiary } \\
(\mathrm{mg} / \mathrm{l})\end{array}$} & \multirow[b]{2}{*}{$\begin{array}{c}\text { Archaean } \\
(\mathrm{mg} / \mathrm{l})\end{array}$} & \multirow[b]{2}{*}{$\begin{array}{c}\text { Surface water } \\
(\mathrm{mg} / \mathrm{l})\end{array}$} \\
\hline & $\begin{array}{l}\text { Minimum } \\
\text { acceptable }\end{array}$ & $\begin{array}{l}\text { Maximum } \\
\text { acceptable }\end{array}$ & & & & \\
\hline $\mathrm{Fe}$ & 0.3 & 1 & $0.090-0.410$ & $0.020-0.290$ & $0.030-0.190$ & $0.110-0.410$ \\
\hline $\mathrm{Al}$ & 0.3 & - & $0.011-2.800$ & $0.004-2.300$ & $0.032-2.740$ & $0.097-2.380$ \\
\hline $\mathrm{Ni}$ & 0.01 & - & $0.001-0.742$ & $0.015-0.134$ & $0.005-0.163$ & $0.005-0.134$ \\
\hline $\mathrm{Pb}$ & 0.05 & 0.1 & $0.370-8.519$ & $0.001-5.556$ & $0.370-6.667$ & $0.001-4.444$ \\
\hline $\mathrm{Br}$ & - & - & $1.630-45.600$ & $0.204-2.020$ & $0.693-4.580$ & $0.118-4.000$ \\
\hline I & - & - & $0.230-0.693$ & $0.111-0.353$ & $0.180-0.644$ & $0.267-0.552$ \\
\hline
\end{tabular}

Table 5. Resistivity and thickness of geoelectrical sections.

\begin{tabular}{|c|c|c|c|c|c|c|c|c|c|c|c|}
\hline \multirow{2}{*}{$\begin{array}{l}\text { Sounding } \\
\text { no }\end{array}$} & \multirow[b]{2}{*}{ Lithology } & \multirow[b]{2}{*}{ Location } & \multicolumn{4}{|c|}{ Resistivity $(\Omega \mathrm{m})$} & \multicolumn{4}{|c|}{ Thickness $(\Omega \mathrm{m})$} & \multirow{2}{*}{$\begin{array}{c}\text { Curve } \\
\text { type }\end{array}$} \\
\hline & & & Layer 1 & Layer 2 & Layer 3 & Layer 4 & Layer 1 & Layer 2 & Layer 3 & Layer 4 & \\
\hline$\overline{\mathrm{R} 1}$ & Alluvium & Cuddalore (NT) & 50.63 & 50.63 & 18.3 & - & 1.36 & 2.04 & $\infty$ & & $\mathrm{Q}$ \\
\hline $\mathrm{R} 2$ & & Cuddalore (OT) & 0.411 & 41.96 & 929.6 & - & 1.2 & 1.5 & $\infty$ & & $\mathrm{A}$ \\
\hline $\mathrm{R} 3$ & & Karaikadu & 2894 & 79.22 & 191.6 & 1.33 & 0.73 & 3.4 & 16.63 & $\infty$ & HQ \\
\hline $\mathrm{R} 4$ & & Panruti & 17.44 & 4.589 & 4999 & - & 3.89 & 5.89 & $\infty$ & & $\mathrm{H}$ \\
\hline R5 & & Arasur & 36.54 & 456.2 & 43.68 & 0.1709 & 1.04 & 2.08 & 16.17 & $\infty$ & $\mathrm{K}$ \\
\hline $\mathrm{R} 6$ & & Veeraperumanallur & 253.8 & 7.311 & 1.52 & 1.371 & 0.62 & 1.93 & 9.84 & $\infty$ & Q \\
\hline $\mathrm{R} 7$ & Tertiary & Kurinchipadi & 35.78 & 5.57 & 2.717 & 5.543 & 0.85 & 3.03 & 14.73 & $\infty$ & $\mathrm{H}$ \\
\hline $\mathrm{R} 8$ & & Naduveerapattu & 32.09 & 2621 & 177.4 & - & 7.2 & 26.8 & $\infty$ & & K \\
\hline $\mathrm{R} 9$ & & Ramapuram & 7156 & 39.74 & 90.83 & 0.4023 & 0.55 & 13.42 & 21.92 & $\infty$ & $\mathrm{HQ}$ \\
\hline $\mathrm{R} 10$ & & Vadakuttu & 159.3 & 5.26 & 9.16 & 3.97 & 0.72 & 2.79 & 40.18 & $\infty$ & $\mathrm{HQ}$ \\
\hline $\mathrm{R} 11$ & & Vadalur & 0.2272 & 30.33 & 849.5 & - & 1.2 & 1.68 & $\infty$ & & $\mathrm{A}$ \\
\hline $\mathrm{R} 12$ & & K. Kallakurichi & 0.5159 & 0.1873 & 0.486 & - & 0.6711 & 19.52 & $\infty$ & & $\mathrm{H}$ \\
\hline $\mathrm{R} 13$ & Archaean & Ariyur & 1.625 & 5.14 & 1928 & - & 0.85 & 9.83 & $\infty$ & & $\mathrm{A}$ \\
\hline $\mathrm{R} 14$ & & Gadilam & 0.0309 & 39.06 & 3.41 & - & 1.2 & 22.5 & $\infty$ & & $\mathrm{K}$ \\
\hline $\mathrm{R} 15$ & & Kalamaruthur & 0.247 & 29.96 & 0.105 & - & 1.02 & 9.78 & $\infty$ & & $\mathrm{K}$ \\
\hline $\mathrm{R} 16$ & & K. Palayam & 0.5249 & 817 & 848.3 & - & 1.2 & 10.52 & $\infty$ & & $\mathrm{A}$ \\
\hline $\mathrm{R} 17$ & & Pasar & 25.28 & 3.33 & 2952 & - & 0.86 & 5.12 & $\infty$ & & $\mathrm{H}$ \\
\hline $\mathrm{R} 18$ & & Sembimadevi & 9.77 & 0.9 & 126.6 & - & 0.88 & 1.3 & $\infty$ & & $\mathrm{H}$ \\
\hline R19 & & Ulundurpettai & 0.1145 & 11.11 & 17.52 & - & 1.2 & 1.33 & $\infty$ & & $\mathrm{A}$ \\
\hline $\mathrm{R} 20$ & & Villivalam & 2.84 & 41.61 & 1549 & - & 2.4 & 42.12 & $\infty$ & & $\mathrm{A}$ \\
\hline
\end{tabular}

that some trace metals such as $\mathrm{Al}, \mathrm{Ni}$ and $\mathrm{Pb}$ exceeded the acceptable limit of WHO (1993) standard.

\subsection{Geophysical investigation}

The Vertical Electrical Sounding (VES) were carried to cover different lithologies, six soundings falls in Alluvium formation, six in Tertiary and eight in Archaean formation. The interpretation was done through the following procedures and 3-4 layers were identified in this region.

The geophysical survey was conducted and the curves were manually plotted and then checked with IPI2Win software and the root mean square (RMS) error was found to be less than $\pm 2 \%$ (Prasanna 2008). Most of the values of manual matched curves and that of IPI2Win v.2.0 software were the same. Thickness of weathered zone estimation and depth of bedrock studies were carried out by using inverse slope and curve matching techniques in comparison to lithology data and the curve matching was found to give fruitful results (Sankaranarayanan and Ramanujachary 1967). Curve matching technique is adopted here with the objective to delineate the thickness of the aquifer zones. The data analyzed by curve matching techniques and IPI2Win for 20 locations were compared. The layer parameters like apparent resistivity $\left(\rho_{a}\right)$ and thickness $(h)$ of different layers were derived. Minor deviations due to subsurface discrepancies and the error in the field data were corrected by smoothening the field curve for easier interpretation. More importance was given to thickness and resistivities of various layers in hydrogeochemical studies. The values obtained by the manual curve matching were used for further studies since the deviation was lesser. A maximum of four layers were identified in few regions, but major parts of the study area have predominantly three layers (table 5).

Interpreted master curves are mostly threelayered curves, namely A type followed by $\mathrm{H}, \mathrm{K}$ 

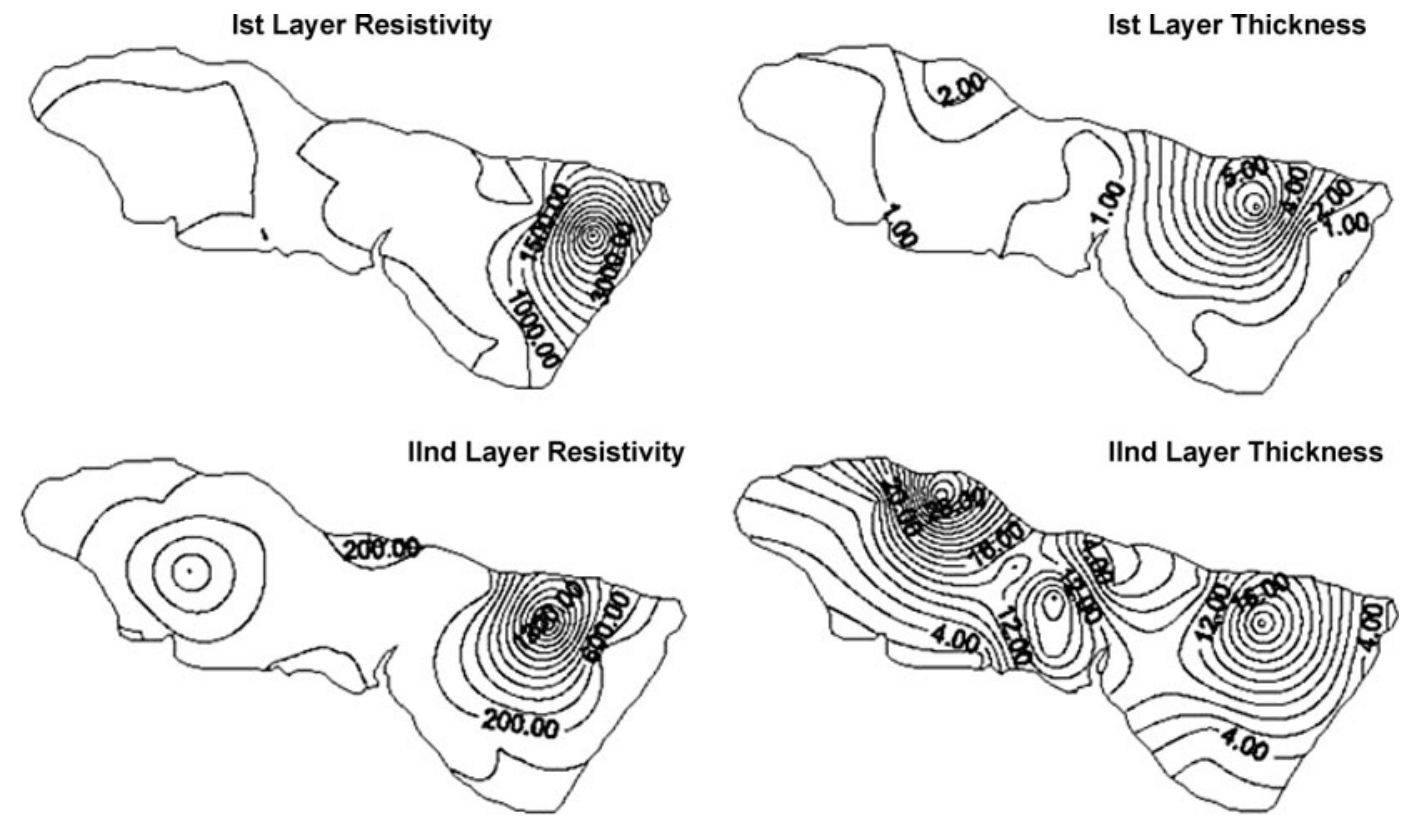

Figure 6. Spatial distribution of resistivity and thickness of first and second layers.

and Q types. VES location numbers 2, 11, 13, 16, 19 and 20 are of A type, whereas the VES no. 4, 7, 12,17 and 18 are of $\mathrm{H}$ type. Four VES curves $(5,8$, 14 and 15) are of $\mathrm{K}$ type, three belong to HQ combination type (3,9 and 10) and two are of $\mathrm{Q}$ type (1 and 16). Generally, A type curve is dominant in Archaean terrain indicating gradually increased resistivity values $(\rho 1>\rho 2>\rho 3)$. Minor representation of $\mathrm{K}$ and $\mathrm{H}$ type curves were also observed in this region indicating few weaker zones. In Tertiary formation, $\mathrm{HQ}$ and $\mathrm{H}$ are dominant curve types indicating that a low resistivity layer is sandwiched between the top soil and sand layer of high resistivity. In Alluvium formation, the aquifer consists of alternate bands of sand, clayey sand and fine sand with clay of varying thickness. Hence a specific dominant layer is not evident in this terrain.

It is observed that in Alluvium terrain, the resistivity value varied from 0.17 to $4999 \Omega \mathrm{m}$ with an average of $420.08 \Omega \mathrm{m}$. The thickness varied from 0.62 to $16.63 \mathrm{~m}$ with an average of $6.16 \mathrm{~m}$. In Tertiary formation, resistivity values varied from 0.18 to $7156 \Omega \mathrm{m}$ with an average of $468.15 \Omega \mathrm{m}$. The thickness varied from 0.55 to $40.18 \mathrm{~m}$ with an average of $12.89 \mathrm{~m}$. In Archaean terrain, resistivity varied from 0.03 to $2952 \Omega \mathrm{m}$ with an average of $350.55 \Omega \mathrm{m}$. The thickness varied from 0.85 to $42.12 \mathrm{~m}$ with an average of $7 \mathrm{~m}$. Generally, the thickness of the first layer shows decreasing trend from Tertiary, Alluvium and Archaean but in the second layer, decreasing trend from Archaean, Tertiary and Alluvium was also observed. The area of low apparent resistivity values indicates the occurrence of relatively good conductors while those with high values indicate poor conductors (Srinivasamoorthy 2004).

In general, three major zones were delineated as weathered, fractured and massive in hard rock region and top soil, sandy layer and clayey layer in sedimentary region. The apparent resistivity values and the thickness have been distributed spatially to develop a resistivity map to get an overall perspective of the study area. The first two layers were selected to prepare the isoresistivity map by using Surfer software. The first layer isoresistivity map indicates that the SE side shows higher resistivity values indicating the presence of top soil and away from the coast the values get decreased (figure 6). Higher thickness was noted in Panruti of Cuddalore sandstone formation due to the deeper water level by overexploitation of groundwater in this region. In Archaean formation, both the resistivity and the thickness values are lesser. In the second layer isoresistivity map, lower resistivity values were noted along the coast indicating the influence of saline water in the coastal aquifer. The resistivity values got increased at locations that are away from the coast and a higher resistivity zone was also observed at K. Palayam of Archaean formation considered as a weathered layer of $10 \mathrm{~m}$ thickness. In the NW side of the Archaean formation, thickness of the second layer is around $40 \mathrm{~m}$ with lesser resistivity values.

The integration of resistivity sounding and geochemistry of groundwater samples was found to be a highly effective method for determining the location of fresh-water areas and the saline water or industrial effluent contaminated zones (Choudhury 
and Saha 2004). All the results revealed that the second layer of low resistivity values in the coastal aquifers determines the saline water contaminated zones, which caused high $\mathrm{Na}$ and $\mathrm{Cl}$ in the groundwater. It is also noted that $\mathrm{Na}$ is the chief cation and $\mathrm{Cl}$ is the dominant anion in all the seasons and in the different formations. Trace element concentrations were also noted higher in areas of more contaminated zones. In noncontaminated zones, the apparent resistivity values were higher indicating the nonpolluted nature of the groundwater.

\section{Conclusion}

This research reports the characterization of ground and surface water in the Gadilam basin by a combined approach of hydrogeochemical and geophysical data. The dominant facies in the entire litho units is $\mathrm{Na}-\mathrm{Cl}$ type indicating saline nature of the water. Spatial distribution of EC indicates anthropogenic impact in the downstream side of the basin. Interpretation of data shows that $\mathrm{Na}, \mathrm{Cl}$ and $\mathrm{K}$ exceed the permissible limits in all litho units. Some trace metals such as $\mathrm{Al}, \mathrm{Ni}$ and $\mathrm{Pb}$ also exceed the acceptable limit of world standard. Resistivity studies reveal that contaminated water from industrial effluent and saline water intrusion with higher ionic concentration was noted near the coastal region. The potable groundwater occurred away from the coastal area.

\section{Acknowledgements}

The authors wish to express their thanks to the Department of Science and Technology, India (DST-SERC) for the necessary financial support to carry out this study. They are also thankful to the School of Environmental Sciences, Jawaharlal Nehru University, New Delhi, India and Department of Earth Sciences, Annamalai University, India for helping in the trace metal analysis of the water samples. The authors are indebted to the anonymous reviewers for their constructive comments and suggestions which improved the manuscript.

\section{References}

Anandhan P 2005 Hydrogeochemical studies in and around Neyveli mining region, Tamil Nadu, India; Unpublished Ph.D Thesis, Department of Earth Sciences, Annamalai University, 189p.

APHA 1998 Standard methods for the examination of water and wastewater; 19th edn., APHA, Washington DC, USASS.
Atwia M G, Hassan A A and Ibrahim A 1997 Hydrogeology, log analysis and hydrochemistry of unconsolidated aquifers south of El-Sadat city, Egypt; J. Hydrol. 5 $27-38$.

Balaram Das, Maity S K and Tarafdar O N 2007 Application of electrical resistivity and induced polarization methods for detection of Fluoride contaminated groundwater; $J$. Geol. Soc. India 69 381-389.

Ballukraya P N and Ravi R 1999 Characterization of groundwater in the unconfined aquifers of Chennai City, India; Part I: Hydrogeochemistry; J. Geol. Soc. India $\mathbf{5 4}$ $1-11$.

Chidambaram S 2000 Hydrogeochemical studies of groundwater in Periyar district, Tamil Nadu, India; Unpublished Ph.D thesis, Department of Geology, Annamalai University.

Choudhury K and Saha D K 2004 Integrated geophysical and chemical study of saline water intrusion; Ground Water 42(5) 671-677.

Das Brijraj K and Kaur P 2007 Geochemistry of surface and sub-surface waters of Rewalsar lake, Mandi district, Himachal Pradesh: Constraints on weathering and erosion; J. Geol. Soc. India 69(5) 1020-1030.

Deevashish Kumar 2002 Characterisation of groundwater flow regime in a crystalline rock through fracture network program; J. Geophys. XXIII 123-129.

Domenico P A and Schwartz F W 1998 Physical and Chemical Hydrogeology, 2nd edn. (New York: Wiley) 506p.

Freeze A R and Cherry J A 1979 Groundwater; PrenticeHall, Inc., Englewood Cliffs, New Jersey, 604p.

Fuge R 1973 Bromine-I, In: Handbook of geochemistry (ed.) Wedepohl K H (Berlin: Springer-Verlag) II(3) 351-1351-4.

ISI 1995 Indian standard specification for driniking water; ISI New Delhi, IS. 10500.

Lakshmanan E, Kannan R and Senthil Kumar M 2003 Major ion chemistry and identification of hydrogeochemical processes of groundwater in a part of Kancheepuram district, Tamil Nadu, India; Environ. Geosci. 10(4) $157-166$.

Mondal N C and Singh V S 2004 A new approach to delineate the groundwater recharge zone in hard rock terrain; J. Geol. Soc. India 87(5) 658-662.

National Academy of Sciences-National Academy of Engineering 1972 Water quality criteria 1972; Washington DC, National Academy of Sciences, 594p.

Panigrahy P I C, Sahu S D, Sahu B K and Sathyanarayana D 1996 Studies on the distribution of calcium and magnesium in Visakhapatnam harbour waters, Bay of Bengal; International Symposium on Applied Geochemistry, Osmania University, Hyderabad, 353-340.

Prasanna M V 2008 Hydrogeochemical studies in the Gadilam River Basin, Tamil Nadu; Unpublished Ph.D Thesis; Department of Earth Sciences, Annamalai University, India, 300p.

Prasanna M V, Chidambaram S, Vasu K, Hameed Shahul A, Unnikrishna Warrier C, Srinivasamoorthy K, Anandhan $\mathrm{P}$ and John Peter A 2008 Identification of the geochemical processes in coastal groundwater using hydrogeochemical and isotopic data: A Case study of the Gadilam river basin in southern India; Indian J. Marine Sci. 37(2) 200-206.

Rabemanana V, Violette S, de Marsily G, Robain H, Deffontaines B, Andrieux P, Bensimon M and Parriaux A 2005 Origin of the high variability of water mineral content in the bedrock aquifers of Southern Madagascar; $J$. Hydrol. 310 143-156.

Ramappa R and Suresh T S 2000 Quality of groundwater in relation to agricultural practices in Lokapavani river 
basin, Karnataka, India; Proceedings of International Seminar on Applied Hydrogeochemistry, Annamalai University, 136-142.

Rengarajan R and Balasubramanian A 1990 Corrosion and scale formation characteristic of groundwater in and around Nangavalli, Salem district, Tamil Nadu; J. Appl. Hydrol. 2 15-22.

Sadashivaiah C, Ramakrishnaiah C R and Ranganna G 2008 Hydrochemical analysis and evaluation of groundwater quality in Tumkur taluk, Karnataka state, India; Int. J. Environ. Res. Public Health 5(3) 158-164.

Sankaranarayanan P R and Ramanujachary K R 1967 An inverse slope method of determining absolute resistivities; Geophys. 32(6) 1036-1040.

Schock M R 1980 Response of lead solubility to dissolved carbonate in drinking water; Journal American Water Works Association 72 695-704.

Singh Abhay K R, Mondal G C, Singh S, Singh P K, Singh T B, Tewary B K and Sinha A 2007 Aquatic geochemistry of Dhanbad, Jharkhand: Source evaluation and quality assessment; J. Geol. Soc. India 69(5) 1088-1102.

Srinivasa Rao Y, Reddy T V K and Nayudu P T 1997 Groundwater quality in the Niva river basin, Chittoor district, Andhra Pradesh, India; J. Environ. Geol. 32(1) $56-63$.

Srinivasamoorthy K 2004 Hydrogeochemistry of Groundwater in Salem District, Tamil Nadu, India; Unpublished Ph.D Thesis, Annamalai University, India.
Srinivasamoorthy K, Chidambaram S, Prasanna M V, Vasanthavihar M, John peter A and Anandhan P 2008 Identification of major sources controlling groundwater chemistry from a hard rock terrain - A case study from Mettur taluk, Salem District, Tamil Nadu, India: J. Earth System Sci. 117(1) 49-58.

Taylor S R and McLennan S M 1985 The Continental Crust: Its Composition and Evolution (Oxford, UK: Blackwell) 312.

Todd D K 1959 Ground Water Hydrology (New York: John Wiley \& Sons).

USGS 1993 Nation water summary 1990-1991: Stream water quality; United State Geological Survey, Water supply paper no. 2400590.

WHO 1993 Guidelines for drinking water quality; World Health Organization, Geneva, 171.

WHO 1996 Guidelines for drinking water quality; World Health Organization, Geneva 1 53-73.

WHO 2003 Lead in drinking-water; Background document for preparation of WHO Guidelines for drinkingwater quality; Geneva, World Health Organization (WHO/SDE/WSH/03.04/9).

WHO 2004 Guidelines for drinking water quality; 3rd edn., Recommendations, Geneva 1515.

Zohdy A A R, Eaton G P and Mabey D R 1974 Applications of surface geophysics to groundwater investigations; Techniques of water resource investigation of the US Geological Survey 2116. 